\title{
Technológiai és munkaszervezési újítások hatása az autóipar térbeli szerveződésére - iparági példa a Volkswagen mintáján
}

\author{
The impacts of technology and work organization \\ innovations on the automotive industry's spatial \\ structure: empirical evidence from Volkswagen
}

\author{
TÚRY GÁBOR
}

TÚRY Gábor: tudományos munkatárs, MTA Közgazdaság- és Regionális Tudományi Kutatóközpont, Világgazdasági Intézet; 1112 Budapest, Budaörsi út 45.; tury.gabor@krtk.mta.hu

KULCSSZAVAK: autóipar; globális értéklánc; munkaszervezés; szerkezeti átalakulás; Volkswagen

ABSZTRAKT: Az autóipar több mint egy évszázad alatt manufakturális kisipari tevékenységből nemzetközi termelési és értékesítési hálózattal rendelkező, globálisan szervezett iparággá fejlődött. A négyütemű robbanómotor szabadalmaztatása óta eltelt 140 év fejlődését végigkísérve nyilvánvalóvá vált, hogy a technológiai és munkaszervezési újítások az átalakulásban kiemelt szerepet töltöttek be. Az újítást támogató döntések hosszú időre meghatározták a vertikum müködését, átalakítva ezzel az ágazat szerkezetét és elősegítve az autóipari tevékenység világméretűvé válását.

A tanulmány az említett szerkezeti átalakulást mutatja be, részletesen ismertetve annak legfontosabb állomásait. Az elemzés rávilágít arra, hogy a bevezetett újítások megváltoztatják az értékláncban részt vevők kompetenciáit, ami hatással van nemcsak az erőforrások vertikális allokációjára, de azok horizontális eloszlására is.

A szerző részletesen tárgyalja a fordista tömeggyártás és a nemzetközi termelés kialakulásának kapcsolatát, amely bizonyos tekintetben az autóipari globalizáció korai szakaszának tekinthető. Az autóipar világméretű szerveződésére a legnagyobb hatást azonban nem a fordista tömegtermelés jelentette, hanem az azt felváltó, a második világháború előtt Japánból elindult szervezeti változások, amelyek világméretű adaptációjára egészen a nyolcvanas évekig kellett várni. A tanulmány részletesen elemzi a bevezetett újítások közül a kiszervezés és a modularizáció folyamatát, taglalva az említett megoldásoknak a termelés szerkezetére és földrajzi mintázatára ható következményeit.

A történeti áttekintés mellett a szerző a Volkswagen 1960 és 2010 közötti fejlődésének bemutatásával is szemlélteti az értéklánc konfigurációjának átalakulását, ami jelentős hatással volt az autóipar térbeli szerveződésére.

Gábor TÚRY: research fellow, Institute of World Economics, Centre for Economic and Regional Studies, Hungarian Academy of Sciences; Budaörsi út 45., H-1112 Budapest, Hungary; tury.gabor@krtk.mta.hu

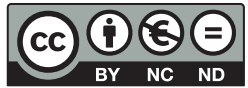


KEYWORDS: automotive industry; global value chain; work organization; structural transformation; Volkswagen

ABSTRACT: During its history, automotive production developed from craft production into a globally organized industry with an international production and distribution network. During the past 140 years, since Nikolaus August Otto's patent of the four-stroke internal combustion engine, it became obvious that innovations in technology and work organization play key roles in the sector's structural transformation and that decisions about them determine their vertical integration. Such innovations also include the distribution of competencies affecting the vertical and horizontal resource allocation.

This study analyses this structural transformation, describes in detail its most important stages and highlights their impact on the spatial production patterns. As a part of this, it examines the relationship between Fordist mass production and the evolution of international production, considered to be an early phase of globalization in the automotive industry. However, the greatest impact on the industry's worldwide organization and geographical distribution was not mass production but rather lean production methods originating from Japan before the Second World War. Nevertheless, the global adaptation of these changes emphasizing the corporate organizational system and in-company relations had to wait until the 1980s. This also changed the relationship between the parent company and its subsidiaries and, in turn, the spatial pattern of automotive production. The study analyses the technology outsourcing and modularization processes and the work organization innovations introduced during the period, explaining their consequences for geographical production patterns.

In addition to the historical overview, the above insights are also confirmed via the investigation of Volkswagen's development between 1960 and 2010. The firm's internationalization process during this period work organization and technological innovations had a significant impact on the company's spatial organization. Through the expansion of opportunities (i.e., developments in technology and labor organization, information technology and communication developments), the geographic structure of Volkswagen's operation underwent significant change. Finally, the geographical transformations also modified the global automotive industry's value chain configurations resulting in its current shape.

\section{Bevezetés}

Az autóipari tevékenység világméretűvé válásával a vállalati szerveződési rendszer felépítése, a vállalaton belüli kapcsolatok szerkezete egyre nagyobb hangsúlyt kapott. Megváltozott az anyavállalat és a kapcsolódó leányvállalatok és beszállítók közötti viszony is, átalakítva ezzel az autóipar térbeli szerveződését. A vállalati tevékenység földrajzi mintázatának átalakulását számos tényező befolyásolta, többek között a kereskedelempolitikai döntések vagy a szállítási és a távközlési rendszerek fejlődése (Dicken 2003; Dunning 1998; Sturgeon, Florida 2000). Emellett a hetvenes években az olajválságok következtében megváltozott piaci környezet is katalizátorként hatott az autógyártás átalakulására (Johnson 2005; Womack, Jones, Roos 1990). Napjainkban a regionális kereskedelemi egyezmények mellett a környezetvédelmi szabályok is jelentősen befolyásolják az ágazat fejlődési irányait, az autóipar térbeli szerveződését.

Henry Ford, a Ford Motor Company alapítójának úttörő fejlesztései óta nyilvánvaló, hogy az autóipar jövője szempontjából a munkaszervezési újítások 
is kulcsszerepet játszanak, és az ehhez kapcsolódó döntések hosszú időre meghatározzák az ágazati vertikum működését. Ford 1923-ban a futószalagos összeszerelés bevezetésével kijelölte azt az új irányt, amelynek nyomán az autóipar túllépett a korábbi kézműves korszakán és beköszöntött a tömegtermelés időszaka. Hasonló paradigmaváltás volt a japán autógyáraknak a második világháborút követően bevezetett termelési módszere, amely a 20. század végén világméretekben forradalmasította a világ autóiparát, lefektetve a mai modern gyártás elveit. A tanulmány elsősorban ezeknek a technológiai és szervezeti innovációknak az elterjedésére és strukturális következményeire összpontosít. A gyártás szervezése nem csupán az ágazati vertikum szerkezetére hat, de a vállalati organizmusnak térbeli lenyomata is van, amely hatással van a termelés világméretü terjedésére. A vállalati döntések kiterjednek a kompetenciák elosztására, amely befolyásolja az erőforrások elosztását és rendszerbe szervezését (Schmied, Grosche 2008; Sturgeon et al. 2009).

A tanulmány ezt a szerkezeti átalakulást kiséri végig, kiemelt figyelemmel a változásnak a termelés térbeli szervezésére gyakorolt hatásaira. Az elemzés alapvetően az autógyártók szempontjából vizsgálja az iparág átalakulását, de a hozzájuk ezer szállal kapcsolódó beszállítókra is külön figyelmet fordít (ez utóbbi ágazati szereplők horizontális és vertikális szerveződésének részletes kifejtése meghaladná a dolgozat kereteit).

A tanulmány első fele az általános elméleti és történeti áttekintés során az autóipar szerkezeti átalakulásának meghatározó állomásait mutatja be, kiemelve a termelés térbeli szerveződésére gyakorolt következményeket. Ezt követően az elemzés a Volkswagen történeti fejlődését végigkísérve példákkal is szemlélteti a technológiai és munkaszervezési átalakulások térbeli hatásait.

\section{Az autóipar szerkezeti átalakulásának állomásai}

A négyütemű belső égésű robbanómotor (Otto-motor) 1876-os szabadalmaztatása óta eltelt 140 év alatt az autóipar manufakturális kisipari tevékenységéből nemzetközi termelési és értékesítési hálózattal rendelkező, globális méretű és szervezettségű iparággá fejlődött. A 19. század végi manufakturális kisipari termelés időszakában a technológiai fejlődésben Európa és azon belül Franciaország és Németország úttörő szerepet játszott (Kukely 2008).

\section{A fordista termelés, a tömegtermelés kezdete}

A 20. század elején az autóiparban Európa addigi vezető szerepét az Amerikai Egyesült Államok vette át. A tengerentúlon sorra jöttek létre a mai napig is meghatározó autógyárak (Ford Motor Company, Buick Motor Company, General 
Motors Corporation). Annak érdekében, hogy eladásaikat növeljék, azaz termékeik minél szélesebb kör számára legyenek elérhetőek, alapvető célként a termelési költségek csökkentését tűzték ki maguk elé. Ebben a törekvésben Henry Fordnak úttörő szerep jutott, aki gyökeresen alakította át az autógyártás addigi struktúráját. A század elejére jellemző egyedi manufakturális gyártást 1913-ban felváltotta az általa alkalmazott - és később róla elnevezett - termelési rendszer, amely nemcsak a tömegtermelés alapjait rakta le, de megteremtette az autóipar vertikumba szerveződését is (Holmes, Snider 2011). Az amerikai vállalatok tartós növekedéséhez az Egyesült Államok kereslete mellett a külföldi piacokon történő megjelenés is hozzájárult. Kezdetben a szállítási költségek csökkentésének köszönhetően, majd a harmincas évektől a kereskedelempolitika akadályainak következtében a felvevőpiacok közelében egymás után jöttek létre az összeszerelő üzemek Dél-Amerikában, Európában és a világ más országaiban, amelyek az amerikai gyárakból odaszállított alkatrészeket használták fel. Ez a korábban nem létező nemzetközi termelési hálózat elképzelhetetlen lett volna a tömegtermelés által megteremtett gyártási kapacitások nélkül, amely jelentősen csökkentette a gyártás és a végső összeszerelés költségét (Sturgeon, Florida 2000). 1928-ban a Ford és a General Motors már 24 országban folytatott összeszerelő tevékenységet, többek között Japánban, Indiában Malajziában és Brazíliában, tíz évre rá pedig egész Európát behálózó termelési hálózat jött létre. Annak ellenére, hogy az 1920-as és 30-as évek autóipara szervezettségi szintjét és integráltságát tekintve nem vethető össze napjaink globális termelési és elosztási rendszerével, a tömegtermelés bevezetése az autóipari globalizáció kezdetének tekinthető (Sturgeon, Florida 2000).

A Ford által bevezetett termelési modell egyetlen típus, az 1908-ban bemutatott Ford $\mathrm{T}$ későbbi piaci sikerén alapult. A nagy darabszámban történő gyártás csökkentette ugyan az egy autóra jutó költségeket, de a mérleg másik oldalán a választékhiány már középtávon éreztette negatív hatását. Az 1920-as években világossá vált, hogy a vállalat egy típus kizárólagosságára alapozott stratégiája alulmaradt a versenytársakkal szemben (Fujimoto, Tidd 1994). Miután 1923-ban Alfred P. Sloan került a General Motors elnöki székébe, a cég által gyártott márkákra támaszkodva decentralizálta a termelést (Holweg 2008), és a vevői igényekhez igazodva szélesítette a kínálatot. Sloan használta az 1924-es éves jelentésében a szlogent: „a car for every purse and purpose” (http:// history.gmheritagecenter.com) azaz egy autó, amely minden pénztárcát és igényt kielégít. Sloannak a piaci kereslethez igazított vállalati megoldásai, valamint a keresletteremtés érdekében bevezetett (Flink 1988) tervezett elavulás $e \operatorname{lve}^{1}$ a tömegtermelés újabb mérföldköveit jelentették. Hasonlóan a rugalmas tömegtermelés bevezetéséhez (Hounshell 1984) - amely az egyes márkák számára szélesebb autonómiát kínáló vezetési felfogást jelentett - ez az intézkedés is sikeresebbnek bizonyult a Henry Ford által alkalmazott merev standardizált termékkínálatnál (Maxton, Wormald 2004). A rugalmas tömegtermelés - mint a 
termelési rendszer újabb fontos állomása - a szélesebb vevői igények kielégítésén keresztül újabb piacok és fogyasztói rétegek bevonásával növelte az értékesítést.

\section{A lean termelés és a posztfordista átalakulás}

A kézmüves termelést felváltó fordista tömegtermelés óta az autóiparban végbement modernizáció motorjai az értéklánc ${ }^{2}$ mentén bevezetett technológiai és szervezeti megoldások (1. táblázat) voltak. Az újítások közül kétségtelen, hogy a második világháborút követően a Japánból kiinduló innovációs megoldások gyakorolták a legnagyobb hatást napjaink globális autóiparára. A modernizáció földrajzi elterjedése azonban egészen az 1970-es, 80-as évekig váratott magára (Holweg 2008). A strukturális átalakulást az olajválság kényszerítette ki, aminek során nyilvánvalóvá vált, hogy a japán vállalatok bizonyos munkaszervezési eljárások korai bevezetésével (Peng, Lee, Tan 2001) komoly versenyképességi előnyre tettek szert a „nyugati országokkal” szemben.

Az 1970-es, 1980-as években a japán vállalatoknál bevezetett termelési rendszernek köszönhetően a kereslet visszaesése kevésbé érintette a szigetország vállalatait, mint az amerikai és a nyugat-európai gyártókat (Bhaskar 1980; Freyssenet 2014). Az Egyesült Államokban a japán autóipari cégek jelentős piaci részesedést szereztek ebben az időszakban (Holweg 2008), ami a szigetország vállalatai számára komoly áttörést jelentett. A lean elvek bevezetése magas minőséget és hatékonyabb gyártást jelentett, amely a versenytársakéhoz képest versenyelőnyt eredményezett, ezzel átalakítva az iparág szereplőinek rangsorát és a termelés földrajzi eloszlását is. A világ autóiparának földrajzi képe átalakult, a szigetország harmadikként csatlakozott az észak-amerikai és európai gyártókhoz.

1. táblázat: Az új technológiák és munkaszervezési eljárások megjelenése az autóipar hagyományos centrumtérségeiben

The emergence of new production technologies and organizational developments in the automotive industry's traditionally core areas

\begin{tabular}{lccc}
\hline \multicolumn{1}{c}{ Technológiák és munkaszervezési eljárások } & USA & Európa & Japán \\
\hline Manufakturális termelés - az autóipar hőskora & 1895 & 1885 & 1907 \\
Fordizmus - a tömegtermelés kezdete & 1913 & 1930 & 1934 \\
Sloani tömegtermelés - marketing- és menedzsmentmegoldások & 1923 & & \\
Toyota-módszer - a hatékony termelés & 1980 & 1980 & 1949 \\
Posztfordizmus & 1973 & 1973 & \\
Kiszervezés és modularizáció - az autóipari tevékenység szerve- & 1980 & 1985 & \multirow{2}{*}{$1950^{*}$} \\
zeti és technológiai átalakítása & & & \\
MQB - autók modulokból, rugalmas és költséghatékony kínálat & & 2007 & \\
(Volkswagen Csoport) & & & \\
\hline
\end{tabular}

* csak kiszervezés.

Forrás: saját szerkesztés Ahrens (2006), Fujimoto, Tidd (1994), Roobeek (1987), Schmitt, Van Biesebroeck (2013), Smith (1968), Smitka (1990) és Womack, Jones, Ross (1990) alapján. 
A japán vállalatok sikerének kulcsa - a második világháborút követő időszakban tökéletesített innováció - a lean termelés volt. Az elnevezés a nyolcvanas években született, a japán gyártási mechanizmusokat az Amerikai Egyesült Államok kormányának megbízásából elemző Womack és szerzőtársai nyomán (Womack, Jones, Ross 1990). A kifejezés magyar megfelelője a karcsúsított gyártás, amely azonban cseppet sem adja vissza a módszer lényegét. Az elképzelés alapja, hogy a termelés során folyamatosan csökkentik a költségeket, így szüntetik meg a nem értéktermelő müveleteket (Tóth 2007). A hatékony és rugalmas termelési folyamatnak köszönhetően időt és költséget takarítanak meg. A kezdetben csupán a termelés során, később egyre több területen bevezetett módszer úttörője a Honda volt (Johnson 2005). A lean gyártási módszer rendszerszintü bevezetése a Toyota nevéhez füződik, ezért a karcsúsított gyártás megfelelőjeként gyakran használják a TPS-t, a Toyota Production System (Toyota termelési rendszer) angol rövidítését.

A gyártási folyamat lean elvek mentén megvalósított optimalizációja érintette az autóipari vertikum szerkezetét is. Ennek az egyik legfontosabb eleme a vertikumon belüli feladatok elosztása. A japán autógyártók 2. világháborút követő válságának a koreai háború (1950-1953) hadiipari megrendelései vetettek véget. Ennek során a gyárak tartva attól, hogy a fellendülés csak időszakos lesz és a felduzzasztott munkaerő-állomány később feleslegessé válik, a növekedést nem a házon belüli termelés növelésével valósították meg, hanem külső beszállítóikat bízták meg a feladattal (Smitka 1990). Így történhetett, hogy míg 1952 és 1957 között a Toyota termelése ötszörösére nőtt, a cégnél foglalkoztatottak száma csupán 12\%-kal bővült. Ez a stratégia jól működött, hiszen a recessziót követően a gyártók könnyűszerrel válogathattak a beszállító cégek között. Ezzel a beruházás anyagi terheit és kockázatát megosztották a beszállítók és az autógyárak között, az autógyárak pótlólagos beruházás nélkül tudták növelni termelésüket (Smitka 1990). A japán vállalatok csak a legszükségesebb stratégiai tevékenységeiket - a tervezést és a végső összeszerelést - tartották meg házon belül. Az értékláncon belüli feladatmegosztás és kompetenciák így alapvetően különböztek a „nyugati” autóipari cégektől. Az 1980-as évek végéig az iparág szereplői között a japán gyártók a legalacsonyabb házon belüli termelési aránnyal rendelkeztek, azaz a késztermékhez szükséges alkatrészek és részegységek gyártásának túlnyomó része a beszállítóknál történt (Chanaron 1995).

A karcsúsított gyártás újításai jelentős mértékben járultak hozzá a hagyományos tömegtermelést megtestesítő fordista rendszert leváltó, illetve meghaladó posztfordista időszak megteremtéséhez (Rodrigue 1999), amely mind vertikálisan, mind területileg átalakította a vállalati termelés szerkezetét. A változás alapvetően a korábbi szervezeti felépítés újragondolását és annak tökéletesítését jelentette. A vállalatok nemzetköziesedésének folyamatában ugyanakkor nem tekinthetünk el a vállalati döntéseket befolyásoló piacvédő mechanizmusok (vám- és nem vámjellegű akadályok) szerepéről sem (Farrell 2008). 
A lean megoldások hatása az autóipari tevékenység térbeli mintázatára nem csupán a japán gyártók által bevezetett technológiai és munkaszervezési újítások mentén értelmezhető, hanem azokat a megoldásokat is figyelembe kell venni, amelyeket a nyolcvanas évektől a világ vezető autógyárai a japán vállalatok által támasztott versenyben alkalmaztak.

\section{Új struktúrák kialakulása, az ágazat szereplőinek válasza a lean gyártásra}

Az 1920-as, 30-as években az amerikai és az európai autógyártók a termelésük során alkalmazott fordista elveket fokozatosan kiegészítették a General Motors által bevezetett rugalmas tömegtermelés módszereivel (Hounshell 1984). Mindezek ellenére az Egyesült Államokban és a nyugat-európai országokban alkalmazott munkaszervezési alapelvek, egészen az 1980-as évek közepéig, nem sokban különböztek a Henry Ford által bevezetett gyakorlattól (Fujimoto, Tidd 1994; Holweg 2008; Oliver, Wilkinson 1988; Tóth 2007). Detroitot - ahogyan a mindennapi szóhasználat az amerikai autóipart nevezi - a japán import támasztotta piaci verseny folyamatos kihívások elé állította a második olajválságot követően. A minőségi problémák, a versenyképtelen ár és az elavult müszaki tartalom az amerikai gyártók számára jelentős versenyhátrányt jelentett az egyre nagyobb piaci részesedést felmutató japán vállalatokkal szemben. A hazai piacon elszenvedett veszteségek radikális költségcsökkentésre kényszerítették az amerikai és az európai gyártókat. A két gazdasági centrumtérség, az Egyesült Államok és Nyugat-Európa a nyolcvanas évek közepén a perifériaterületek (Kanada, Mexikó, Dél-Európa) integrálásával csak időlegesen volt képes ellensúlyozni versenyhátrányát. Világossá vált, hogy a költségek csökkentésére rendszerszinten kell megoldást találni.

A szerkezeti átalakítás az iparág teljes vertikumát érintette. A nyugateurópai és az észak-amerikai autógyártók megváltoztatták értékláncszerkezetüket a japán vállalatok által támasztott verseny miatt. Ennek leglátványosabb lépése az autógyártók (OEM) által végzett tevékenységek egy részének kiszervezése volt. Ennek eredményeképpen csökkentették a házon belüli termelést, és egyre több tervezési és gyártási funkciót adtak át a vezető beszállítóiknak (Chanaron 1995; Humphrey, Memedovic 2003). A tendencia a fejlett országok autóiparát jellemezte, tehát azokra a cégekre vonatkozott, amelyek technológiai ráfordításaik és piaci jelenlétük alapján nemzetközileg jelentős szereplőknek számítottak.

Az autóiparban végrehajtott strukturális átalakulás, bizonyos értéklánctevékenységek kiszervezése és a moduláris termelés (a definíciót lásd később) bevezetése paradigmaváltást jelentett az iparágban (Baldwin, Clark 1997; Dicken 2003), a technológiai és munkaszervezési újítások pedig elősegítették az iparág 
globalizációját (Camuffo 2001). Annak ellenére, hogy a globalizációnak, a modularizációnak és a kiszervezésnek más-más a jelentése, valójában elválaszthatatlanok egymástól (Camuffo 2001; Collins, Bechler, Pires 1997). Az autó egészének moduláris alapokon történő tervezése és gyártása, iparági példákból kiindulva, megvalósulhat jelentős kiszervezés nélkül is (Helper et al. 1999; Takeishi, Fujimoto 2001). Ugyanakkor Helper és szerzőtársai (1999) rávilágítanak arra, hogy a modularizáció bevezetése elősegítette a kiszervezést. Történetileg a kiszervezés megelőzte a moduláris tervezést és felépítést (Smitka 1990), hiszen a japán vállalatok a gyártásszervezésben már a 2. világháborút követően éltek ezzel az eljárással. A rendszer konszolidációjával a kiszervezés a moduláris felépítés bevezetésének irányába mutatott a tervezés és a gyártás esetében (Collins et al. 1997). A kiszervezés és a modularizáció az elmúlt három évtizedben olyan mértékben alakította át a résztvevők számát és viszonyrendszerét, ami a korábbitól teljesen eltérő földrajzi és termelési struktúrát eredményezett az autóiparban.

\section{A moduláris rendszer bevezetése}

A szakirodalom a modularizációval kapcsolatban három folyamatot különít el (Baldwin, Clark 1997, 2000; Fujimoto 1999; He, Kusiak 1997). ${ }^{3}$ Az első a termék szerkezetét érintő felépítés (moduláris tervezés), amely alapvetően egy technológiai-szerkezeti megoldás. A moduláris rendszer a gyártástervezés során szabványosított kapcsolódási felülettel (csatlakozások és kompatibilitás) rendelkező, önálló funkcionális egységek sorozatával az adott célnak megfelelő egységeket hoz létre. A modulokat felépítő önálló funkcionális egységek változatainak köszönhetően többcélú, sokoldalú felhasználást tesznek lehetővé (Camuffo 2001). A termék felépítésénél alkalmazott szerkezeti modularizációval az autógyárak - az addig jellemző komplexitást lecserélve - a szerkezeti egyszerüség elvét valósították meg (Baldwin, Clark 1997). A Henry Ford által 1913-ban bevezetett csereszabatos alkatrészek használata csupán az adott modell egyes darabjai közötti helyettesíthetőséget teremtette meg, a modularizáció már a tervezéskor megvalósította a sokoldalú felhasználást. A gyártás során szabványosított szabályozó és kényelmi berendezéseket (motorszabályozás és vezérlés, hütés-fütés) alkalmaztak, de érintette ez a belső tér különböző elemeit (ülések, belső borítás), vagy az egységes padlólemezre (platform) épített és különböző motorokkal szerelt járműveket is. Ez utóbbi magában foglalja a padlólemezen kívül a meghajtást, a váltóművet és a műszerfal belső elemeit (Wilhelm 1997). Az eljárás az autóiparban megnövelte a kapcsolódási, illetve beépíthetőségi pontok számát, ezzel lehetőség nyílt egy adott modul széles körű (több típusban történő) felhasználására.

A másik folyamat a termelés modulárissá tétele, amely a nagyobb (moduláris) egységek felhasználását és összeszerelését jelenti. Az „előszerelés” segítségé- 
vel egyszerüsítik a járművek készre szerelési munkafolyamatait. A modulok összeszerelését leginkább a beszállítók végzik. A folyamat az Egyesült Államokban a nyolcvanas évek közepétől figyelhető meg, amikor az autógyárak a kiszervezés során nemcsak egyszerü munkafolyamatokat, hanem komplett egységek gyártását is külső cégeknek adták át (Sturgeon et al. 2009). A termelés modulárissá tételének (moduláris egységek alkalmazása) köszönhetően komplett rendszerek ${ }^{4}$ illetve összetett alkatrészek és részegységek ${ }^{5}$ használatával a végső összeszerelés során az OEM-ekben komplett rendszereket (műszerfal, motorvezérlés, belső és külső világítás stb.) építenek be, miközben a korábbi élőmunka-igényes és aprólékos munkafolyamatokat kiszervezték. ${ }^{6}$ Ezzel átalakították az irányítási és ellenőrzési hatásköröket és a koordinációs mechanizmusokat (Gereffi, Humphrey, Sturgeon 2005; Sturgeon, Lester 2004). Az értéktermelési folyamat átalakult, hiszen korábban az autógyárak által a részegységeken elvégzett összeszerelési folyamatok a beszállítók első köréhez (tier 1) kerültek, akik a beszállítói rendszer alacsonyabb szintjén lévő vállalatokat összefogva rendszerintegrátorként is közreműködtek.

A harmadik folyamat a vállalatok közötti modularizáció. Ez a vállalatok közötti kapcsolatokat érinti, átalakítva az ellátási lánc egészét (Camuffo 2001; Helper et al. 1999; Robertson, Ulrich 1998). Az autógyártók, mérlegelve a költségeket, bizonyos értéktermelő folyamatokat az értéklánc mentén kiszerveznek vagy házon belül oldalnak meg. A termék felépítése és a szervezeti rendszer közötti kapcsolatot számos szerző megerősíti (Baldwin, Clark 2000; Takeishi, Fujimoto 2001), az azonban nem tisztázott, hogy a moduláris felépítés milyen hatásmechanizmusok mentén befolyásolja a vállalatok közötti kapcsolatokat (Camuffo 2001). Takeishi és Fujimoto (2001) az autógyártók és a beszállítók közötti kompetencia- és feladatmegosztásra hoz példákat a Volkswagen és a Daimler autógyárak kilencvenes években létesített üzemeiből, ahol a beszállítók a kezdetektől fogva kulcsszerepet játszottak a végső összeszerelés területén.

A modularizáció értelmezésével összefüggésben Takeishi és Fujimoto (2001) megemlíti, hogy a modularizáció három jelentését az elemzések gyakran összemossák, illetve pontatlanul alkalmazzák, hiszen amíg az európai vállalatoknál a modularizáció leginkább a kiszervezés oldaláról értelmezheto", addig a japán vállalatoknál esetében az újításoknak a termelés során alkalmazott moduláris egységek bevezetésénél van jelentősége.

\section{A tevékenységek kiszervezése}

A nyolcvanas évek közepétől alapvető átalakulás ment végbe az autóipari értéklánc szerkezetében, amelyet kiszervezésnek hívunk. Ennek során az autógyárak egyre több szolgáltatási és gyártási tevékenységet helyeznek ki „házon kívülre", a tulajdonukat képező vagy független vállalatok számára. Bár a folyamat nem volt előzmények nélküli (lean termelés), az átalakulás ezúttal az Amerikai Egyesült Államokból indult ki. A változás leginkább az autógyáraknál 
foglalkoztatottak számában érhető tetten. Az autóiparban 1990 és 1996 között létrejött 103 ezer új állás nagy része a beszállítóknál realizálódott (Sturgeon, Florida 2000). Az „autógyárakban” kevesebb munkáskézre volt szükség, a gyártási feladatok egyre nagyobb hányada került át a beszállítókhoz. A beszállítók jelentőségének növekedése a feladatok átadásánál vált kézzelfoghatóvá, hiszen a 2000-es években a gyártási folyamat során a gépjárművet 75\%-ban a beszállítóknál szerelték össze (Unger 2012). A hozzáadott érték 80\%-át (Dannenberg, Kleinhans 2005), az autóipari kutatás-fejlesztésnek pedig már 50\%-át adják külső cégek (European Commission 2004).

A kiszervezés az autógyárak költségcsökkentési céljai (végső soron a versenyképesség javítása) és az autóipari vertikumon belüli pozícióik erősödése mellett a termelés földrajzi eloszlásával kapcsolatos feltételek változását is magával hozta. A kiszervezésnek köszönhetően egy telephely létesítésének kockázata (Camuffo 2001) és anyagi terhei nemcsak megoszlottak az autógyárak és a beszállítók között, de nagyságrendekkel terhelték meg az utóbbiakat (Sturgeon, Florida 2000). Így a vállalatok új piacokra történő belépése, az ágazat nemzetköziesedése dinamikusabban és sikeresebben mehetett végbe (Sturgeon, Florida 2000).

Az autóipari vertikum szerkezetében végbement másik lényeges változás, hogy a modularizációnak és a kiszervezésnek köszönhetően az első körös (tier 1) beszállítók feladatai megnőttek. A többletfeladatokhoz tőkeigényes vállalatokra volt szükség, ami az iparág konszolidációjához vezetett (Dannenberg, Kleinhans 2005). A kilencvenes évektől ezért egymás után jöttek létre a ma is létező globális méretű és szervezettségű autóipari beszállító cégek (Sturgeon et al. 2009), világméretű rendszerbe szervezve az autóipari beszállítást. Ezek a cégek egyszerre több, egymás versenytársainak számító autógyárral is kapcsolatban állnak, ${ }^{7}$ és világméretü termelési rendszerükben globálisan szervezik partnereik áruval és szolgáltatással történő ellátását. Az autógyárak részéről a beszállítók kiválasztása globális rendszerben értelmezhető, ahol nekik is nagyobb a mozgásterük, és így egy tervezési és gyártási feladathoz szükséges beszállító kiválasztása befolyásolja a termelés földrajzi eloszlását. ${ }^{8}$ A kiszervezésnek köszönhetően a vállalat úgy alakítja a beszállítói összetételét, hogy minimalizálja a költségeit. A termelési kapacitások optimális elosztásával az autógyáraknak nagyobb mozgástere van, hiszen az esetleges veszteségeket a beszállítók kiválasztásával vagy a költségek áthárításával csökkenthetik (Sturgeon, Florida 2000; Sturgeon et al. 2009). Amennyiben az adott piacon a termék árában jelentkező árfolyamköltség vagy egyéb kereskedelmi költség túl magas, akkor a részfeladatok földrajzi áthelyezésével, illetve a beszállítók körének optimalizációjával ellensúlyozhatja veszteségeit (Schmid, Grosche 2008). Erre példa, hogy az Amerikai Egyesült Államokban 1990 és 2008 között megszűnő 435 ezer munkahely nagy része nem a gépjármü-összeszerelést érintette, hanem a 297 ezer fös csökkenés az alkatrészeket és részegységeket eloállító beszállítóknál jelentkezett (Platzer, Harrison 2009). 


\section{A szerkezeti változások hatása az értéklánc átalakulására}

Az autóiparban az elmúlt évtizedekben a termelés szerkezeti változása az új munkaszervezési eljárások és a technológiai újítások integrálását jelentette. A szervezeti változások, a beszállítók és az autógyárak közötti feladatmegosztás átalakulása újabb lökést adott a világméretű termelési rendszerek kialakulásának (Smitka 1990). Az 1950-es évektől a japán autóipari cégek által alkalmazott kiszervezés, a külső erőforrások segítségével megvalósított termelésbővülés mára a nagy nemzetközi autóipari vállalatok számára mindennapos gyakorlattá vált. Egy olyan, erősen integrált iparágról beszélhetünk, amelynek teljesítménye számos szereplő együttműködésén alapul, ahol az autógyártók egyre inkább csak a stratégiai területek ellenőrzését tartják a vállalaton belül, míg a beszállítók egyre több feladatot hajtanak végre önállóan. A részegységgyártás egyre nagyobb mértékű leválasztásával már az autóipari vállalatok felelnek jellemzően a föegységekért (motor, sebességváltó) és a karosszériaelemekért, valamint a végső összeszerelést is ők végzik (Schmid, Grosche 2008).

Az 1960-as, 1970-es évektől kezdődően a járművek műszaki tartalmának (felszereltségének) bővülése (Veloso, Kumar 2002), azaz a technológiai fejlesztés miatt a beszállítók szerepének növekedése folytatódik. A kiszervezés folyamata, valamint a járművekbe beépített technológia fejlődése előrevetíti a beszállítók súlyának növekedését az értékláncban (1. ábra) (Dannenberg, Kleinhans 2005; Ernst \& Young 1998; Svéhlik 2005). A napjainkban már hagyományosnak mondható posztfordista autóipari értéklánc egyre több eleme kerül át független beszállítókhoz (Dannenberg, Kleinhans 2005; Schmid, Grosche 2008; Svéhlik 2005), csökkentve az autógyárak eddigi feladatait.

A feladatok átadása megváltoztatja a munkafolyamatokat és az azokhoz szükséges erőforrások vertikális és horizontális eloszlását. Az autógyárak számára az új termelési egység megvalósításának eszköz- és költségigénye alacsonyabb lesz. Az autógyártóknál a végső összeszerelés egyszerűbbé válik, az összeszereléshez szükséges idő csökken (Sturgeon, Florida 2000). A másik jelentős változás az, hogy a kilencvenes évektől a moduláris rendszerek bevezetésével a szervezeti és technológiai oldalon is megteremtették a feltételeket (ezzel átvéve a lean termelés egyik legfontosabb technológiai/szervezeti újítását) a gyártási tevékenységek rugalmas szétválasztására és elosztására (Schmid, Grosche 2008), amelynek következtében az értékláncfolyamat is átalakult. Az OEM-ek nemzetközi munkamegosztása a globális értékláncfolyamatok mentén valósult meg, és szervezettségében, méreteiben meghaladja a korábbi évek szintjét (Schmid, Grosche 2008). Más szerzők, mint Sturgeon és Van Biesebroeck (2011), valamint Sturgeon és Memedovic (2011) ugyanakkor rámutattak arra, hogy az autóipar termelési és értéklánca - igazodva a piaci kereslethez - nem világméretekben, hanem regionálisan szerveződik. 
OEM-ek jelenleg

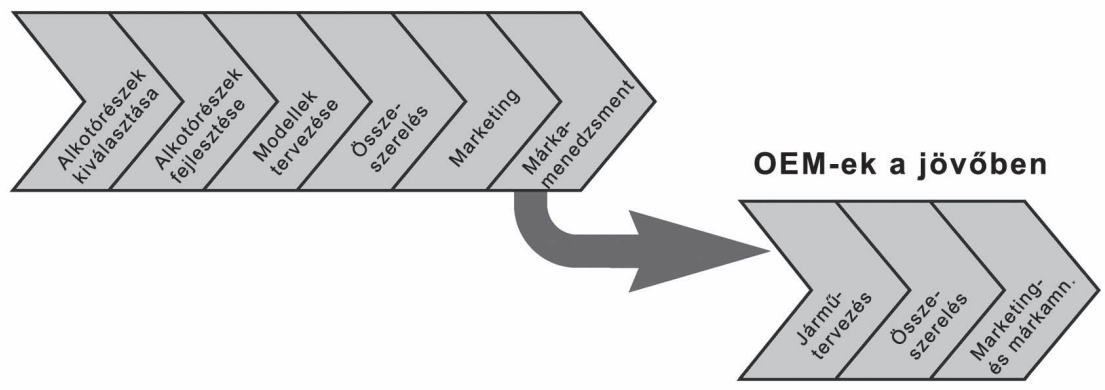

Forrás: Ernst \& Young $(1998,4$.$) .$

\section{Technológiai és munkaszervezési újítások, a termelés térbeli mintázatának átalakulása a Volkswagennél}

A Volkswagen térbeli termelésszervezésének átalakulását elemezve figyelembe kell venni azt a tényt, hogy az ötvenes évektől a Volkswagen mind méretében, mind tevékenységének földrajzi kiterjedésében jelentős átalakuláson ment keresztül. A nyugat-németországi cégből egy multinacionális, a kilencvenes években pedig egy globális vállalatcsoport jött létre, a piacok bővülésével és a külföldi termelés elindításával párhuzamosan a vállalat belső struktúrája és termelési rendszere is átalakult (Pries 2003). A Volkswagen a vállalati fejlődés során nem tudta kivonni magát a nemzetközi politikai és gazdasági folyamatok (konjunktúraváltozások, kormányzati politikák stb.) következményei alól, amelyek így hatással voltak a vállalat termelésének térbeli szerveződésére is (Jürgens 1998). A tanulmánynak ebben a részében megvizsgáljuk, hogy a bevezetett technológiai és munkaszervezési eljárások milyen módon alakítják át a termelés térbeli mintázatát.

A termelés szerkezetében megvalósított változások szükségességét először az 1960-as évek végén a piac jelezte. A vállalat legfontosabb külpiacán, az Egyesült Államokban nyilvánvalóvá vált, hogy az addigi fordista stratégia nem tartható tovább. ${ }^{9}$ A Volkswagen Bogárral kapcsolatban felmerült műszaki és közlekedésbiztonsági problémák a fejlett piacokon (Észak-Amerika, Nyugat-Európa) történő eladások további csökkenését okozták. ${ }^{10} \mathrm{~A}$ németországi termelés magas költsége, majd a japán autógyártók által támasztott verseny alapvető szerkezeti változtatásokat tett szükségessé a vállalatnál. Az új stratégia a termékszerkezetben a fordista termelés és a sloani ${ }^{11}$ elképzelés között helyezkedett el (Jürgens 1998). Ennek műszaki alapját - az Auto Union átalakításá- 
val, az NSU felvásárlásával - az 1969-ben létrehozott Audi NSU Auto Union AG Volkswagenbe integrálása jelentette. A közös alapokon nyugvó, de eltérő márkával és felszereltséggel gyártott típusok ekkor jelennek meg először a Volkswagennél. A vállalat számára - a műszaki fejlesztés mellett - a másik fontos célt az értéklánc racionalizációja jelentette, amelyhez jelentősen hozzájárult a kiszervezés, a modularizáció és a standardizálás is (Collins et al. 1997).

\section{A modularizáció folyamata és hatásai a Volkswagenre}

A moduláris termelés úttörői az amerikai General Motors és az olasz Fiat voltak (Camuffo 2001), e vállalatok a nyolcvanas évek végén tették meg az első lépéseket a termelési szerkezet átalakítása felé. Példájukat a kilencvenes években követték a világ nagy autógyártói, többek közt a Ford, a Daimler-Chrysler, a Mercedes-Benz és a Volkswagen is.

A közös platformra épülő modellek gyártását a kezdetektől fogva alkalmazta a Volkswagen (Pries 2003), azonban a teljes vállalati müködésre kiterjedő integrált rendszerről a kilencvenes évekig nem beszélhettünk. Az egységes padlólemezre történő felépítménytervezést a Volkswagent 1993 és 2002 között igazgató Ferdinand Piëch vezette be (Pries 2003; Volkswagen 2014; Wilhelm 1997). A megoldást a Toyota korábban már alkalmazta, de Piëch volt az, aki nevet (Plattformstrategie) is adott neki (Johnson 2005, 321). A hatékonyság növelésének érdekében a nyolcvanas években elindult terjeszkedés (SEAT, majd a kilencvenes években a Škoda) - az új márkák és a bővülő modellválaszték miatt - a kilencvenes években indokolttá tette a moduláris építőkockák használatát (Jürgens 1994; Pries 2003). A közös alkatrészek szélesebb körű alkalmazásával megvalósult a standardizálás, amely növelte az azonos osztályok közötti műszaki együttműködés lehetőségét, így az egyes termelési pontok között is nőttek a kooperáció lehetőségei (Pries 2003; Túry 2016).

Míg a platformrendszer csak egy autóosztályon belül jelentett kompatibilis felhasználhatóságot az alkatrészek és részegységek szélesebb körben történő felhasználása és csereszabatossága szempontjából, addig a moduláris termelés (a Volkswagennél a Modul-Strategie elnevezést használják) bevezetése a felhasznált egységek szempontjából már az egyes osztályok közötti csereszabatosságra is lehetőséget adott (2. ábra). A termelés során felhasznált alkatrészek és részegységek beépítésekor az egyes osztályok ${ }^{12}$ közötti átjárhatóság kulcskérdéssé vált.

A modularizáció megteremtette a feltételeket a gyártási tevékenységek rugalmas szétválasztására és elosztására (Schmid, Grosche 2008). A technológiai fejlesztéseknek köszönhetően a gépjárművekhez használt alkatrészek és modulok (részegységek) csereszabatossága (a standardizálás, a modellek közötti átjárhatóság) növekedett. Műszaki tartalmukat tekintve az egyes modellek közötti eltérések megmaradtak - igazodva az adott márka, illetve típus 
2. ábra: A moduláris építőrendszer fejlődése

The evolution of the modular assembly toolkit

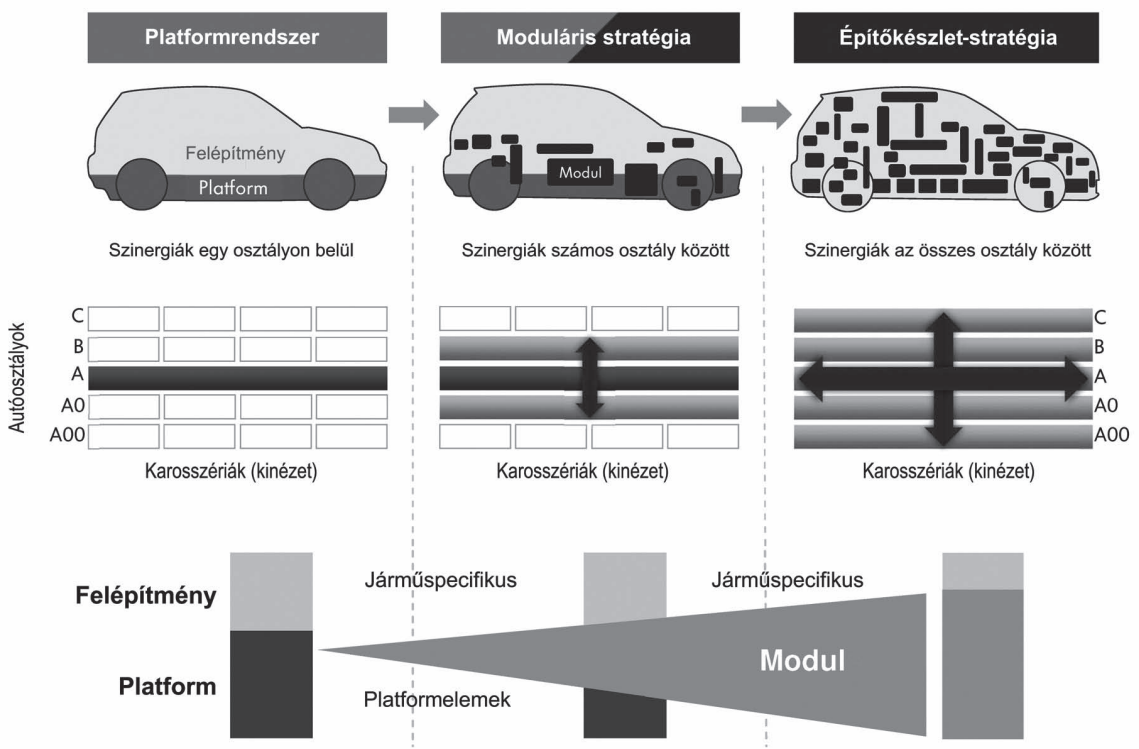

Forrás: Lemke (2013, 6.); Winterkorn (2010, 4.).

által képviselt tartalomhoz -, ugyanakkor a felhasznált alkatrészek kombinációjának köszönhetően folyamatosan nőtt az azonos alkatrészek aránya. Ez a tervezési és kivitelezési költségek csökkenésén túl jelentős méretgazdaságossági előnnyel is járt, továbbá az egyes termelési helyek közötti kapcsolat erősödéséhez és az együttműködés magasabb szintjéhez vezetett (Audi Hungaria Motor 2014). A bevezetett műszaki újítások nemcsak az autó szerkezetét érintették, de forradalmi hatással voltak az értéklánc egészére is, átalakították az OEM-ek és az értéklánc többi szereplőjének feladatait és kapcsolatrendszerét (Dicken 2003; He, Kusiak 1997; Helper et al, 1999; Smahó 2012). Jó példa a közös műszaki alapokon nyugvó típusok gyártására, hogy a győri Audi Hungaria Motor által gyártott alkatrészeket a Volkswagen-csoport több mint 30 telephelyén építik be (www.audi.hu).

A standardizálás nem rekedt meg, a Volkswagennél tovább dolgoztak a technológia továbbfejlesztésén, amelyet moduláris építőlem-stratégiának (Modulare Baukastenstrategie) neveztek el. (Ennek az egyik típusa az MQB - Modularer Querbaukasten, keresztmotoros építőkészlet.) A technológia - amelyet 2007-ben vezettek be (Autogramm Wolfsburg 2012) - tovább növelte a közösen felhasználható alkatrészek számát.

A tanulmány statisztikai adatok segítségével mutatja be (2. táblázat) a vállalati értéklánc földrajzi mintázatában történt változásokat, amelynek so- 
rán megvizsgálja a bevezetett technológiai-munkaszervezési újítások szerepét is. A Volkswagen térbeli szerveződését az európai és tengeren túli leányvállalatoknál (brazíliai, argentin, dél-afrikai stb.) az egy foglalkoztatottra jutó összeszerelt személygépjárművek számának alakulásával szemléltetjük. Azt vizsgáljuk, hogy az egyes országokban, illetve földrajzi régiókban található Volkswagen-leányvállalatnál van-e statisztikailag is kimutatható eltérés az összvállalati értékhez képest, és hogy a vizsgált öt évtized alatt megfigyelhetők-e változások. Számításainkban a helyi foglalkoztatottak, az előállított és az értékesített gépjárművek számát használtuk (a leányvállalati szintű adatok részletessége ezt tette lehetővé). A vizsgálatunkat arra az alaptézisre építjük, hogy a termelési folyamat során az egyes munkafolyamatok térbeli elkülönítése kimutatható a késztermékelóállítás és a foglalkoztatottak területi eloszlása alapján. Vagyis azt vizsgáltuk, hogy az adott helyen munkaigényes (elsősorban végösszeszerelés) vagy technológiaintenzív (motorok és más föegységek gyártása) feladatokat végeznek-e. Bizonyos telephelyek (pl. Mexikó) esetében azonban e felosztás mentén nem tudunk egyértelmü magyarázatot adni az alacsony kibocsátási értékre. Ezekre később a kiszervezés folyamatának tárgyalásakor kapunk választ.

A 2. táblázat alapján olyan vállalat képe rajzolódik ki, amely a tevékenységét egyre inkább nemzetközi méretekben szervezi, ahol az erőforrások területi elosztása egyre inkább összetett, sokszerelős rendszerben valósul meg. A hatvanas években a vállalat hazai (nyugat-németországi) és külföldi telep-

2. táblázat: Az egy foglalkoztatottra jutó összeszerelt gépjárművek számának területi különbségei a Volkswagennél (a vállalati átlagtól való eltérés)

Regional differences in the number of assembled vehicles per employee at Volkswagen

(Deviation from the corporate average)

\begin{tabular}{lccccccccccc}
\hline \multicolumn{1}{c}{ Országok } & 1960 & 1965 & 1970 & 1975 & 1980 & 1985 & 1990 & 1995 & 2000 & 2005 & 2010 \\
\hline Volkswagen-átlag & 12,2 & 13,1 & 11,8 & 11,4 & 10,6 & 9,4 & 11,5 & 14,6 & 16,5 & 16,3 & 20,9 \\
\hline NSZK & 1,1 & 1,0 & 0,4 & $-1,0$ & $-1,2$ & 0,2 & $-1,0$ & $-3,8$ & $-5,3$ & $-5,6$ & $-9,0$ \\
Nyugat-Európa & $\ldots$ & $\ldots$ & $\ldots$ & 14,7 & 13,7 & 25,2 & 10,6 & 14,4 & 15,0 & 12,3 & 8,8 \\
Kelet- és Közép-Európa & $\ldots$ & $\ldots$ & $\ldots$ & $\ldots$ & $\ldots$ & $-0,7$ & $-0,8$ & $-1,4$ & 2,9 & 2,3 & $-1,7$ \\
Brazília & $-9,1$ & $-6,6$ & $-2,0$ & 1,3 & 0,4 & $-1,7$ & $-1,3$ & 4,8 & 1,5 & 17,1 & 22,3 \\
Argentína & $\ldots$ & $\ldots$ & $\ldots$ & $\ldots$ & $-3,2$ & $-3,4$ & $-2,8$ & 2,1 & $-5,2$ & $-8,0$ & $-7,5$ \\
Nigéria & $\ldots$ & $\ldots$ & $\ldots$ & $\ldots$ & $\ldots$ & $-2,4$ & $-10,4$ & $\ldots$ & $\ldots$ & $\ldots$ & $\ldots$ \\
Dél-afrikai Köztársaság & 1,7 & $-3,8$ & $-2,1$ & $-0,8$ & $-2,4$ & $-4,4$ & $-5,6$ & $-4,6$ & $-8,6$ & 1,0 & 0,4 \\
Kína & $\ldots$ & $\ldots$ & $\ldots$ & $\ldots$ & $\ldots$ & $\ldots$ & $-5,4$ & 0,6 & 2,9 & 4,1 & 21,5 \\
India & $\ldots$ & $\ldots$ & $\ldots$ & $\ldots$ & $\ldots$ & $\ldots$ & $\ldots$ & $\ldots$ & $\ldots$ & 8,6 & $-7,8$ \\
USA & $\ldots$ & $\ldots$ & $\ldots$ & $\ldots$ & 11,9 & $-0,2$ & $\ldots$ & $\ldots$ & $\ldots$ & $\ldots$ & $\ldots$ \\
Mexikó & & $-13,1$ & $-2,0$ & 0,9 & $-1,2$ & $-2,7$ & $-2,0$ & 1,5 & 8,9 & 3,6 & 7,6 \\
\hline
\end{tabular}

... - nincs adat, nincs termelés.

Forrás: Volkswagen 1960 és 2010 közötti éves pénzügyi jelentései alapján a szerző számításai. 
helyei (tengerentúli üzemek) között a technológiafejlettségben és az élőmunka-ráfordításban (Pries 2003) jelentős különbségek voltak (2. táblázat). Az 1970-es évektől a vállalat tevékenységének területi képe megváltozik. A Német Szövetégi Köztáraságon kívül Mexikóban is jelentős fö- és részegységgyártás épült ki (Volkswagenwerk 1974). Az 1980-as évek végén a Volkswagen de México már az anyavállalaton (Volkswagen AG) kívül az észak-amerikai gyáregységgel (Volkswagen of America) és a brazíliai leányvállalattal (Volkswagen do Brasil) is kialakít beszállítói kapcsolatokat (Volkswagen 1988), amely kapcsolatok a kilencvenes évekig globálissá válnak (Bott 2008). A következő meghatározó időszak a nyolcvanas évek derekától figyelhető meg. Németországban - hasonlóan Közép- és Kelet-Európához, Argentínához és a termelésbe a 2000-es évek elején bekapcsolódó Indiához - igen alacsony az egy foglalkoztatottra jutó összeszerelt gépjárművek száma. Ugyanakkor Brazília, Mexikó, Nyugat-Európa és Kína impozáns értékei a másik oldalt képviselik, náluk a fajlagos gépjármű-kibocsátás jóval a vállalati átlag felett van.

Az esetenként igen jelentős különbség a termelés hatékonyságának területi eltéréseivel nem indokolható, mivel az 1980-as évektől a Volkswagen üzemeiben a technológiai standardok és a hatékonysági elvárások - az adott munkafolyamathoz viszonyítva - azonosnak tekinthetők (Pries 2003). Egy globális rendszerben működő vállalatnál az ilyen mértékű különbséget feltételezésünk szerint a termelés térbeli szerkezetének átalakulásában kell keresnünk. Pries (2003) az 1990-es évektől kezdődő időszakot a termékválaszték és a piaci stratégia esetében megkülönböztette a korábbi fejlődési szakaszoktól, és úgy írja le, mint a regionálisan kialakított egyedi jegyekkel rendelkező globalizált platformok korszakát. Vagyis a Volkswagen az egy gépjárműre jutó tervezési és gyártási költségek csökkentése érdekében a standardizálás, a kereslet hatékonyabb kiszolgálása érdekében pedig az együttműködés (telephelyek közötti tudás- és feladatmegosztás) jegyeit mutatja. A vállalaton belüli feladatmegosztás és specializáció iskolapéldája az Audi Hungaria Motor, amely a vállalat legnagyobb motorgyáraként kiterjedt vállalaton belüli beszállítási kapcsolatokkal rendelkezik.

A moduláris rendszer bevezetésének köszönhetően a vállalaton belüli integráció elmélyült, a standardizálás, a csereszabatos alkatrészek alkalmazása méretgazdaságossági megfontolásokból lehetővé tette bizonyos termelési szakaszok specializációját. A gyártási folyamat egyes fázisait technológiailag és földrajzilag egyaránt könnyebb szétválasztani, a méretgazdaságosság következtében egy adott részegység előállítása területileg is koncentrálttá válik. Ez megerősíti a tanulmány elején megfogalmazott állítást, miszerint a technológiai újítások lehetővé teszik a termelés területi szerveződésének átalakulását, vagyis a gyártási tevékenységek rugalmas szétválasztásán (Schmid, Grosche 2008) keresztül az értéklánc mentén végzett folyamatok térbeli allokációját. 


\section{Kiszervezés}

A moduláris rendszer bevezetése mellett a vállalati tevékenység térbeli szerveződése során a kiszervezésnek is meghatározó jelentősége van. A Volkswagennél az 1990-es évek elején a kiszervezés új formája jelent meg; a folyamat szorosan összefügg a korábban tárgyalt modularizációval. A korábban ismertetett vállalatok közötti modularizáció területén - vagyis az értéktermelő folyamatok értéklánc mentén történő elosztásában - a vállalat úttörő szerepet játszott. A cég volt az első autógyártó, amely nemzetközi szinten hozta létre a moduláris konzorciumot: 1992-től a mexikói Pueblában, 1994-től a csehországi Mladá Boleslavban, ${ }^{13}$ 1996-tól pedig a brazíliai Resendében (Camuffo 2001). Ezt megelőzően a Volkswagen más gyáraiban is tesztelte az új munkaszervezési eljárást (Businessweek 1996). Így a kelet-németországi Moselben elsőként vezették be a beszállítóknak egyre nagyobb kompetenciát adó moduláris konzorciumot, amellyel drasztikusan csökkent az autók készre szerelésének ideje és a vállalatnál közvetlenül foglalkoztatottak száma. A vállalat más európai üzemeiben is megvalósította a beszállítók integrálását, így a spanyolországi Matorellben és a portugáliai Setubalban (Frigant, Lung 2002; Miltenburg 2003).

1992-ben a Volkswagen mexikói üzemében új időszámítás kezdődött. Az új kollektív szerződés értelmében a vállalat csak a végső összeszerelést végző foglalkoztatottakat tartotta meg, az autógyártáshoz kapcsolódó többi értéklánc-tevékenységek (beszállítói és gyártási részfolyamatok) átkerültek a beszállítókhoz (Espinosa 2012). Az átalakítás - amellett, hogy sokkal feszesebb együttműködést igényelt a termelésben részt vevő vállalatok között - a munkavállalók számának radikális csökkenését eredményezte. Az 1990-ben még 20 ezer föt foglalkoztató pueblai gyár 1994-ben már csak 14 ezer főt alkalmazott (Espinosa 2012). A kiszervezésnek köszönhetően a „gyár mellett” közvetetten mintegy 80 ezer ember dolgozott a Volkswagen számára (Montiel 2002). Az alapfeladatok egy részének kiszervezése így módosította a helyi Volkswagen munkavállalóinak számát és a vállalat által végzett feladatok körét is, megváltoztatva ezzel a vállalat térbeli szerveződését.

A Volkswagennél a kiszervezés és a moduláris termelés valódi iskolapéldája azonban a Volkswagen Caminhões e Ônibus resendei üzemében 1996-ban létrehozott moduláris konzorcium volt (Neto et al. 2013). A moduláris konzorcium elképzelésének lényege, hogy a brazíliai telephelyen olyan termelési rendszert alakítottak ki, amelyben minden összeszerelési tevékenységet átadtak kilenc első körös beszállítónak (3. ábra). ${ }^{14} \mathrm{~A}$ tevékenységek a megszokott módon zajlottak, a különbség „csupán” annyi, hogy az első körös beszállítók nemcsak az alkatrészek és a részegységek beszállítói voltak, de a végső összeszerelést is ők végezték (Collins et al. 1997; Pires 1998), ezzel a vállalat fizikailag is integrálta őket a Volkswagen helyi gyártóbázisába. A feladatok kiszervezésének mértéke kiugróan magas volt a resendei teherautóüzemben, a Volkswagen a tevékenységeknek mindössze 15-20\%-át végezte (Gawer 2009; Junior 2011). A kiszerve- 
3. ábra: A moduláris termelés sematikus rajza a Volkswagen resendei üzemében Diagram of the modular production system of the Volkswagen Caminhões e Ônibus in Resende

\begin{tabular}{|c|c|c|c|}
\hline $\begin{array}{l}\text { Vezetőfülkeváz } \\
\text { Tamet (Brazília) }\end{array}$ & \multirow{6}{*}{$\rightarrow$} & $\begin{array}{c}\text { Vázösszeszerelés (karosszéria) } \\
\text { Iochpe-Maxion (Brazília) }\end{array}$ & \multirow{5}{*}{$\begin{array}{c}\text { Teherautó- és buszössze- } \\
\text { szerelő sor }\end{array}$} \\
\hline$\downarrow$ & & $\begin{array}{c}\text { Felfüggesztés, tengelyek és fékek } \\
\text { Rockwell (USA) }\end{array}$ & \\
\hline \multirow[t]{4}{*}{$\begin{array}{c}\text { Festés } \\
\text { Eisenmann (Németország) }\end{array}$} & & $\begin{array}{c}\text { Kerekek és gumiabroncsok } \\
\text { Iochpe-Maxion (Brazília) } \\
\text { Borlen (Brazília) } \\
\text { Bridgestone (Japán) }\end{array}$ & \\
\hline & & $\begin{array}{c}\text { Motor, váltó és hűtőrendszer } \\
\text { MWM (Németország) } \\
\text { Cummins (USA) }\end{array}$ & \\
\hline & & $\begin{array}{l}\text { Vezetőfülke-összeszerelés } \\
\text { VDO Kienzle (Németország) }\end{array}$ & \\
\hline & & & $\begin{array}{c}\text { Végső minőségellenőrzés } \\
\text { Volkswagen }\end{array}$ \\
\hline
\end{tabular}

Forrás: Collins, Bechler, Pires $(1997,503$.$) .$

zéssel a termelési költségek 20\%-os megtakarításán túl az egy autóra jutó időráfordítást is 10\%-kal csökkentették az összeszerelő soron (Collins et al. 1997). A Volkswagen a saját gyárában ennek következtében igen kevés munkavállalót foglalkoztatott (Marx et al. 1997). Az üzem 1500 munkavállalójából mindössze 200 volt Volkswagen-dolgozó, a többi alkalmazott a beszállítókhoz tartozott (Abreu et al. 2000; Corrêa, de Miranda 1998). A statisztikai számbavétel során ez a helyzet jelentősen torzítja a valós adatokat (az egy Volkswagen-munkavállalóra jutó értékteremtést).

A kiszervezésre másik példaként a brazíliai Sao Carlosban létesített motorgyár hozható fel. Az 1996 óta működő üzemben a beszállítóknak a kezdetektől fogva jelentős szerepük volt, 2000-ben az üzemben foglalkoztatott 450 munkásból 250 a beszállítóknál dolgozott (Gomes, Filho 2002). A külső cégek nemcsak a szolgáltatások területén (az adminisztráció fenntartása) müködtek közre, de a termelésben is részt vettek. Az 1996-os resendei moduláris konzorcium bevezetése után a Sao Carlos-i üzemben is felvetődött a feladatok túlnyomó részének átadása a beszállítók számára, de az előzetes vizsgálatok alapján ez nem hozta volna az elvárt eredményeket, így végül elvetették az ötletet. A moduláris konzorcium bevezetése így a vállalat resendei üzemét érintette csupán, a feladatok hasonló mértékủ átadásáról a vállalat többi telephelyén nem beszélhetünk.

Az 1990-es évek végén a Volkswagennél a kiszervezés mellett volt egy azzal ellentétes folyamat is, amely egyre több főegység és alkatrész gyártásának vállalaton belüli integrálását eredményezte (Automotive News Europe 1997). A vállalat vezetőinek indoklása szerint - a költségek figyelembevétele mellett - a legfontosabb cél a munkavállalók megtartása volt. A Volkswagen németországi 
gyárai közül a braunschweigi különösen erős a műanyag alkatrészek gyártása területén, a kasseli és a wolfsburgi üzemekben pedig sebességváltók, kipufogórendszerek, műanyag alkatrészek, kormányrendszerek, első és hátsó tengelyek gyártása folyik. A Volkswagen Wolfsburgban az alkatrész- és részegységgyártásban több mint 10 ezer fót foglalkoztat. A Volkswagen-csoport alkatrészgyártásában jelentős az európai területek túlsúlya, ezen belül Németország felülreprezentáltsága (Gutzmann, Lupa 2010).

Ezek - az értéklánc mentén történt - kiszervezés általi munkaszervezési változások a munkavállalók számát éppúgy befolyásolták, mint az egyes telephelyek, illetve leányvállalatok feladatköreit, módosítva ezáltal a vállalat tevékenységének földrajzi mintázatát.

\section{Összegzés}

A kisipari termelést felváltó fordista tömegtermelés bevezetése rávilágított arra, hogy az autóiparban lejátszódó átalakulást leginkább az értéklánc mentén bevezetett műszaki és szervezeti megoldások idézték elő. A termelés során bevezetett újítások a mai napig meghatározó szerepet játszanak, hiszen a döntések hosszú időre meghatározzák az autóipari vertikum működését. A szerző arra kereste a választ, hogy az új megoldások hatásai megjelennek-e a vállalati tevékenység térbeli szerveződésében. Az elemzés végigkísérte a technológiai és munkaszervezési újításoknak az ágazat térbeli szerveződésére kifejtett hatásait. A tanulmány eredményei megerősítették, hogy a változások jelentősek, és nemcsak vertikálisan alakították át az iparágat, hanem a termelés földrajzi mintázatára, azaz a vállalatok horizontális működésére is hatással voltak. A szerző e megállapításokat - a fordista és a lean termelés idevágó következményeinek számbavétele mellett - a történeti áttekintés során példákkal is alátámasztotta. A kiszervezés és a modularizáció bevezetésével, az 1980-as évektől technológiai és szervezeti értelemben is megteremtődtek azok a feltételek, amelyek lehetővé tették a gyártási tevékenységek rugalmas szétválasztását és elosztását, létrehozva ezzel a termelési hálózatok globális szerveződését.

A Volkswagen fejlődésének történeti vizsgálata alátámasztotta, hogy a technológiai és munkaszervezési megoldások jelentős hatással voltak a globális vállalat termelésének térbeli szerkezetére, a munkaerő és a termelési kapacitások regionális allokációjára. A nyolcvanas évektől bevezetett kiszervezés a beszállítói oldalon is nemzetközivé formálta a vállalatok működését. Az 1990-es években bizonyos telephelyek esetében az alapfeladatok kiszervezésével tovább csökkentették a közvetlenül alkalmazott munkavállalók számát és az adott telephelyek feladatait, módosítva ezzel a vállalat tevékenységének földrajzi mintázatát. A modularizáció bevezetésével kialakult standardizálás egységessé tette a vállalat kínálati portfólióját, amelynek eredményeképpen a termelés során 
jobban érvényesülhettek a méretgazdaságossági szempontok. Olyan központi termelő és elosztó egységek jöttek létre, amelyek egy adott tevékenység elvégzésére specializálódtak (alkatrész-, részegységgyártás stb.), és amelyek ellátják a nemzetközi vállalat összes termelési pontját - így téve globálissá a vállalati tevékenyég területi mintázatát.

\section{Jegyzetek}

1 Az eladások növelése érdekében a termékek hamarabb avulnak el, mint korábban. Ennek oka lehet, hogy technikailag mennek tönkre „idő előtt”, vagy a divat és reklám miatt igen hamar elavulttá válnak, amivel a termék tulajdonosát a régi cseréjére ösztönzik.

2 Az értéklánc a terméknek vagy szolgáltatásnak az elképzeléstől (ötlet), a tervezésen át a különböző termelési fázisokon (a nyersanyag megmunkálásától a kapcsolódó tevékenységek és szolgáltatások igénybevételéig) keresztül a fogyasztóhoz való eljutáshoz, a vásárlást követő szolgáltatásokhoz, illetve a használatot követő elhelyezéshez (hulladékkezelés, újrafelhasználás) szükséges tevékenységek sorozata (Porter 1985).

3 Sako és Murray (2000) némiképp eltérően különíti el a modularizációhoz köthető folyamatokat. Hármas felosztást alkalmazva a moduláris tervezés, a moduláris használat és a termelés modulárissá tétele hármasát nevezi meg.

4 Komplett rendszer: autóelektronika (belső szórakoztató és teljes rendszerek), autóklíma, hütőés fütőrendszerek, fékek és fékrendszerek, motorelektronika és vezérlés, kormányrendszer.

5 Összetett (bonyolult) alkatrészek és részegységek: karosszériaelemek (komplett ajtók), tengelyek, váltók, autóbelső (székek, kárpitok, borítások), műszerfal.

6 A kompetenciaátadás mértéke autógyáraként eltérő volt (bővebben lásd Morris, Donnelly 2006).

7 A gépjárművek utasvédelmi berendezésének gyártásával foglalkozó svéd Autoliv vagy az iparág legnagyobb beszállítója az Egyesült Királyságban bejegyzett Delphi a világ meghatározó autógyárainak (pl. BMW, Daimler, FCA, Ford, GM, Honda, Kia-Hyundai, PSA, Volkswagen) szállít alkatrészeket és komplett egységeket (Autoliv 2016; Delphi 2016).

8 A Porsche autógyár a Boxter típus összeszerelésére addigi beszállítója helyett új céggel kötött megállapodást. Az addig Finnországban összeszerelt gépkocsikat a jövőben az ausztriai Grazban készítik (Mayer 2008).

9 Tolliday (1995) a Volkswagen Bogár meghatározó és csaknem kizárólagos szerepére utalva ezt az időszakot „bogár-monokultúrának”, Jürgens (1998) pedig „bogárkultusznak” nevezte. Az egy típus meghatározó jellege miatt a vállalat termelése ebben az időszakban „fordistább” volt a Ford termelésénél is.

101973 és 1976 között az Amerikai Egyesült Államokban történő értékesítés a felére esett vissza (Volkswagen 2008).

11 Alfred P. Sloan, az amerikai General Motors vezérigazgatója a húszas évektől a Ford Motor Company sikereire válaszul átszervezte a GM termelését. Az egyik legfontosabb újítása a termékkínálat szélesítése volt. Az eladások felfuttatása érdekében a különböző márkákat úgy kombinálta, hogy az minden társadalmi osztály számára elérhető legyen, ezzel széles társadalmi rétegek számára kínált termékeket (Mészáros 2007).

12 A közúti járműveket, hogy egymástól megkülönböztessék őket, műszaki tartalmuk alapján osztályokba sorolják. A különböző szempontok eltérő rendszerezést és elnevezést eredményeznek (lásd az európai Euro NCAP osztályozása, a belga ACEA besorolása, az amerikai Alliance of Automobile Manufacturers, az ACRISS Car Classification Code-ja vagy a United States Environmental Protection Agency besorolása). Az eltérések ellenére az osztályozások egyben közösek, a felosztás egyben hierarchia is, ahol az egy osztályba tartozó járművek azonos vagy nagyon hasonló müszaki tartalommal rendelkeznek. 
13 Részben tesztelve a reakciókat, részben pedig tapasztalatgyüjtés miatt, amelyeket a rendszer eseteges nyugat-európai bevezetése során felhasználhat (Pavlínek 2008).

14 A moduláris termelés és a moduláris konzorcium kifejezését célszerủ egymástól elkülöníteni (Pavlínek 2008). Előbbi a moduláris elemek minél szélesebb alkalmazását jelenti, utóbbinál az együttmüködés (vagy kiszervezés) sokkal nagyobb mértékű, hiszen az egyes modulokat gyártó vállalatokat is a termelésbe integrálják, egészen az összeszerelési folyamatokig.

\section{Irodalom}

Abreu, A., Beynon, H., Ramalho, J. R. (2000): The dream factory - VW's modular production system in Resende, Brazil. Work, Employment and Society, 2., 265-282. http://doi.org/bfv88q

Ahrens, T. (2006): Lean production: Successful implementation of organisational change in operations instead of short term cost reduction efforts. Lean Alliance, Germany

Audi Hungaria Motor (2014): Interjú az Audi Hungaria Motor Kft. Kísérleti Motorépités és Analizis részlegének vezetöjével, Győr, 2014. február 5.

Autogramm Wolfsburg (2012): Der Baukasten des Erfolgs. Ausgabe 11/2012. Volkswagen AG - Konzernkommunikation, Wolfsburg. http://autogramm.volkswagen.de/11_10/wolfsburg/wolfsburg_01.html (Letöltés: 2014. március 1.)

Autoliv (2017): Autoliv annual report 2016. Autoliv, Stockholm https://www.autoliv.com/ Investors/Financial\%20Reports/AR2016.pdf (Letöltés: 2017. március 1.)

Automotive News Europe (1997): VW outsourcing trend ends. October 27 http://europe.autonews.com/ article/19971027/ANE/710270814/vw-outsourcing-trend-ends (Letöltés: 2014. március 1.)

Baldwin, C. Y., Clark, K. B. (1997): Managing in an age of modularity. Harvard Business Review, 75., 84-93.

Baldwin, C. Y., Clark, K. B. (2000): Design rules. The power of modularity. MIT Press, Cambridge

Bhaskar, K. N. (1980): The future of the world motor industry. Kogan Page, London

Bott, A. (2008): Die Zulieferverflechtungen von Volkswagen de México: Ein Beispiel für die Raumwirksamkeit von Globalisierungs- und Restrukturierungsprozessen. Dissertation. Rheinischen Friedrich-WilhelmsUniversität, Mathematisch-Naturwissenschaftlichen Fakultät, Bonn

Businessweek (1996): VW's factory of the future. October 6. http://www.businessweek.com/stories/199610-06/vws-factory-of-the-future (Letöltés: 2015. március 1.)

Camuffo, A. (2001): Rolling out a world car: globalization, outsourcing and modularity in the auto industry. MIT (IMVP Working papers)

Chanaron, J-J. (1995): Constructeurs/fornisseurs: specifités et dynamique d'evolution des modes relationnels. Actes du GERPISA, 14., 9-22.

Collins, R., Bechler, K., Pires, S. (1997): Outsourcing in the automotive industry: From JIT to modular consortia. European Management Journal, 5., 498-508. http://doi.org/b89q4t

Corrêa, H. L., de Miranda, N. G. M. (1998): Supply network management in the Brazilian automotive industry. Integrated Manufacturing Systems, 5., 261-271. http://doi.org/bbntrz

Dannenberg, J., Kleinhans, C. (2005): The coming age of collaboration in the automotive industry. Mercer Management Journal, 17., 88-94.

Delphi (2017): Delphi annual report 2016. Delphi Automotive PLC, Gillingham http://s2.q4cdn.com/ 607989273/files/doc_financials/2016/Annual/Delphi_AnnualReport2016_20170406.pdf (Letöltés: 2017. március 1.)

Dicken, P. (2003): Global shift: Reshaping the global economic map in the 21st century. Sage, London

Dunning, J. H. (1988): Explaining international production. Unwin Hyman, London

Ernst \& Young (1998): Profile of tomorrow's automotive supplier. http://www.autoindustria.com/ encuentro/documentos/automotive_supplier_capgemini.pdf (Letöltés: 2016. március 23.)

Espinosa, M. M. (2012): Volkswagen de México: reestructuración, flexibilidad y conflictos, si somos Americanos. Revista de Estudios Transfronterizos, 2., 19-49. 
European Commission (2004): The European competitiveness report 2004 - Competitiveness and benchmarking. Brussels, SEC (2004)1397.

Farrell, R. (2008): Japanese investment in the world economy: A study of strategic themes in the internationalisation of Japanese industry. Edward Elgar Publishing, Chelthenham, Northampton http://doi.org/b6kz

Flink, J. J. (1988): The automobile age. MIT Press, Cambridge

Freyssenet, M. (2014): La production automobile mondiale, des quatre continents et des principaux pays constructeurs, 1898-2013. Document d'enquête: quatre tableaux et sept graphiques commentés. http://freyssenet.com/files/*\%20Production\%20automobile\%20mondiale\%20par\%20continent\% 20et\%20pour\%20les\%20principaux\%20pays\%20constructeurs,1898\%202013.xlsx～(Letöltés: 2016. január 10.)

Frigant, V., Lung, Y. (2002): Geographic proximity and supplying relationship in modular production. International Journal of Urban and Regional Research, 4., 742-755. http://doi.org/dwxchh

Fujimoto, T. (1999): The evolution of a manufacturing system at Toyota. Oxford University Press, New York

Fujimoto, T., Tidd, J. (1994): The UK and Japanese automobile industry: adoption and adaptation of Fordism. Actes du GERPISA, 11., 69-108. (Historie et Hybridation du Fordisme; 11.)

Gawer, A. (2009): Platforms, markets and innovation. Imperial College Business School, London http://doi.org/b6k2

Gereffi, G., Humphrey, J., Sturgeon, T. J. (2005): The governance of global value chains. Review of International Political Economy, 1., 78-104. http://doi.org/bdfk3g

Gomes, A., Filho, A. (2002): Assembler control of the supply chain: The case of an engine plant in Brazil. Actes du GERPISA, 1., 49-60.

Gutzmann, U., Lupa, M. (2010): Kompetenz mit Tradition und Leidenschaft: Der Komponenten-Werkzeugbau bei Volkswagen in Braunschweig. Volkswagen Aktiengesellschaft, Wolfsburg

He, D., Kusiak A. (1997): Design of assembly systems for modular products. IEEE Transactions on Robotics and Automation, 5., 646-655. http://doi.org/drdkm7

Helper, S., MacDuffie, J. P., Pil, F., Sako, M., Takeishi, A., Warburton, M. (1999): Modularization and outsourcing: implications for the future of automotive assembly. Project Report: International Motor Vehicle Program (IMVP). MIT, Boston

Holmes, T. J., Snider, J. T. (2011): A theory of outsourcing and wage decline. American Economic Journal: Microeconomics, 2., 38-59. http://doi.org/fwnw4p

Holweg, M. (2008): The evolution of competition in the automotive industry. In: Parry, G., Graves, A. (eds.): Build to order: The road to the 5-day car. Springer-Verlag, London, 13-34. http://doi.org/cbwkjt

Hounshell, D. A. (1984): From the American system to mass production 1800-1932: The development of manufacturing technology in the United States. John Hopkins University Press, Baltimore

Humphrey, J., Memedovic, O. (2003): The global automotive industry value chain: What prospects for upgrading by developing countries. UNIDO, Strategic Research and Economics Branch

Johnson, R. A. (2005): Six men who built the modern auto industry. Motorbooks, St. Paul

Junior, W. F. S. (2011): Supply chain management in the Brazilian automobile industry: Bottlenecks for steadier growth. International Journal of Lean Thinking, 1., 24-45.

Jürgens, U. (1994): VW at the turning point - Success and crisis of a German production concept. Actes du GERPISA, 10., 91-108.

Jürgens, U. (1998): The development of Volkswagen's industrial model, 1967-1995. In: Freyssenet, M., Mair, A., Shimizu, K., Volpato, G. (eds.): One best way? Trajectories and industrial models of the world's automobile producers. Oxford University Press, Oxford, New York, 273-310.

Kukely Gy. (2008): A gépipar gazdaságföldrajza. In: Vidéki I. (szerk.) Fejezetek ipar- és közlekedésföldrajzból. ELTE Eötvös Kiadó, Budapest, 175-196.

Lemke, H. (2013): Die Modul-Baukasten-Strategie des Volkswagen Konzerns im Zusammenspiel mit globalen Systemlieferanten. http://www.rkw-bw.de/rde/pdf/RKW-Organisation-2013/VortragLemke-VW.pdf (Letöltés: 2015. augusztus 8.)

Marx, R., Zilbovicius, M., Salerno, M. S. (1997): The "modular consortium" in a new VW truck plant in Brazil: new forms of assembler and supplier relationship. Integrated Manufacturing Systems, 5. 292-298. http://doi.org/cbpxkv 
Maxton, G. P., Wormald, J. (2004): Time for a model change: Re-engineering the global automotive industry. Cambridge University Press, Cambridge http://doi.org/cjd994

Mayer, B. (2008): Porsche to switch Boxster assembly to Magna Steyr. Automotive News Europe, June 25. http://www.autoweek.com/article/20080626/FREE/491595533 (Letöltés: 2012. március 1.)

Mészáros J. (2007): Szervezetszociológia közgazdászoknak. In: S. Nagy K. (szerk.): Szociológia közgazdászoknak. Typotex Kiadó, Budapest, 175-192.

Miltenburg, P. (2003): Effects of modular sourcing on manufacturing flexibility in the automotive industry - A study among German OEMs. PhD thesis, Erasmus University Rotterdam http://repub.eur.nl/pub/1039/ EPS20030300RG_9058920526_MILTENBURG.pdf (Letöltés: 2015. november 19.)

Montiel, Y. (2002): Jornada reducida o despido. La participación democrática de los trabajadores en las decisiones de Volkswagen en Puebla. Ponencia presentada en el Dixième Rencontre Internationale du Gerpisa, 6-8 de junio, París

Morris, D., Donnelly, T. (2006): Are there market limits to modularisation? International Journal of Automotive Technology and Management, 3., 262-275. http://doi.org/b3bjb8

Neto, M. S., Pires, S. R. I., Silva, E. M. (2013): Modularity and relational mechanisms of governance: An analysis of modular consortium and industrial condominium. Journal of Operations and Supply Chain Management, 1., 74-90. http://doi.org/b6k3

Oliver, N., Wilkinson, B. (1988): The Japanization of British industry. Basil Blackwell, Oxford

Pavlínek, P. (2008): A successful transformation? Restructuring of the Czech automobile industry. PhysicaVerlag, Heidelberg, New York

Peng, M. W., Lee, S-H., Tan, J. J. (2001): The keiretsu in Asia: Implications for multilevel theories of competitive advantage, Journal of International Management, 4., 253-276. http://doi.org/cd945s

Platzer, M. D., Harrison, G. J. (2009): The U.S. automotive industry: National and state trends in manufacturing employment. Congressional Research Service Washington, DC. http://digitalcommons. ilr.cornell.edu/key_workplace/666

Porter, M. E. (1985): The competitive advantage: Creating and sustaining superior performance. Free Press, New York

Pires, S. R. I. (1998): Managerial implications of the modular consortium model in a Brazilian automotive plant. International Journal of Operations \& Production Management, 3., 221-232. http://doi.org/fmcsrh

Pries, L. (2003): Volkswagen in the 1990s: Accelerating from a multinational to a transnational automobile company. In: Freyssenet, M., Shimizu, K., Volpato, G. (eds.) Globalisation or regionalisation of European automobile industry? Palgrave, London, New York, 51-72.

Robertson, D., Ulrich, K. (1998): Planning for product platforms. Sloan Management Review, 4., 19-31. http://doi.org/c8kjz2

Rodrigue, J-P. (1999): Globalization and the synchronization of transport terminals. Journal of Transport Geography, 4., 255-261. http://doi.org/c8kjz2

Roobeek, A. (1987): The crisis in Fordism and the rise of a new technological paradigm. Futures, 2., 129-154. http://doi.org/dtdvvq

Sako, M., Murray, F. (2000): Modules in design, production and use: Implications for the global automotive industry. A paper prepared for the International Motor Vehicle Program (IMVP) Annual Sponsors Meeting 5-7 October, Cambridge, MA

Schmid, S., Grosche, P. (2008): Management internationaler Wertschöpfung in der Automobilindustrie - Strategie, Struktur und Kultur. Bertelsmann Stiftung, Gütersloh

Schmitt, A., Van Biesebroeck, J. (2013): Proximity strategies in outsourcing relations: The role of geographical, cultural and relational proximity in the European automotive industry. Journal of International Business Studies, 5., 475-503. http://doi.org/b6k4

Smahó M. (2012): A tudástranszferek rendszerei és a járműipar. In: Rechnitzer J., Smahó, M. (szerk.): Jármüipar és regionális versenyképesség: Nyugat- és Közép-Dunántúl a kelet-közép-európai térségben. Universitas-Győr Nonprofit Kft., Győr, 109-142.

Smith, P. H. (1968): Wheels within wheels: a short history of American motor car manufacturing. Funk \& Wagnalls, New York

Smitka, M. (1990): The invisible handshake: The development of the Japanese automotive parts industry. Business and Economic History, Second Series, 19., 163-171. 
Sturgeon, T. J., Florida, R. (2000): Globalization and jobs in the automotive industry. Final report to the Alfred P. Sloan Foundation, International Motor Vehicle Program, Center for Technology, Policy and Industrial Development. Massachusetts Institute of Technology, Cambridge

Sturgeon, T. J., Lester, R. (2004): The new global supply-base: New challenges for local suppliers in East Asia. In: Yusuf, S., Altaf, M. A., Nabeshima, K. (eds.): Global production networking and technological change in East Asia. Oxford University Press, Oxford, 35-87.

Sturgeon, T. J., Memedovic, O., Van Biesebroeck, J., Gereffi. J. (2009): Globalisation of the automotive industry: main features and trends, International Journal of Technological Learning, Innovation and Development, 1-2., 7-24.

Sturgeon, T. J., Memedovic, O. (2011): Mapping global value chains: Intermediate goods trade and structural change in the World economy. UNIDO Working Paper, 05/2010.

Sturgeon, T. J., Van Biesebroeck, J. (2011): Global value chains in the automotive industry: an enhanced role for developing countries? International Journal of Technological Learning, Innovation and Development, 1-3., 181-205.

Svéhlik Cs. (2005): Kihívások és trendek a világ autógyártási struktúrájában. PhD értekezés. Nyugat-magyarországi Egyetem

Takeishi, A., Fujimoto, T. (2001): Modularization in the auto industry: interlinked multiple hierarchies of product, production, and supplier systems. IIR Working Paper, WP\#01-02. Hitotsubashi University, Tokyo

Tolliday, S. (1995): From „Beetle monoculture" to the „German model”: The transformation of Volkswagen, 1967-1991. Business and Economic History, 2., 111-132.

Túry G. (2016): A Volkswagen tevékenységének nemzetközivé válása, a termelés térbeli mintázatának átalakulása a hatvanas évektől napjainkig. Területi Statisztika, 6., 591-618. http://doi.org/b6k5

Tóth Cs. L. (2007): A karcsúsított gyártás - a lean production. Magyar Minőség, 8-9., 2-13.

Unger, T. (2012): Insights from an automotive industry perspective. APEC Chemical Regulators' Forum, Singapore, 30 March 2012

Veloso, F., Kumar, R. (2002): The automotive supply chain: Global trends and Asian perspectives. ERD Working Paper, 3.

Volkswagen (1988): Geschäftsbericht 1987. Volkswagen AG, Wolfsburg

Volkswagen (2008): Historical notes 7: Volkswagen chronicle - Becoming a global player. Volkswagen AG, Wolfsburg

Volkswagen AG (2014): Modulare Baukastenstrategie http://www.volkswagenag.com/content/vwcorp/ content/de/investor_relations/Warum_Volkswagen/MQB.html (Letöltés: 2015. december 13.)

Volkswagenwerk (1974): Bericht für das Geschäftsjahr 1973. Volkswagenwerk AG, Wolfsburg

Wilhelm, B. (1997): Platform and modular concepts at Volkswagen - Their effect on the assembly process. In: Shimokawa, K., Jürgens, U., Fujimoto, T., (eds.): Transforming automobile assembly: Experience in automation and work organization. Springer, New York, 146-156. http://doi.org/b6rn2w

Winterkorn, M. (2010): 50. Ordentliche Hauptversammlung der Volkswagen Aktiengesellschaft. 22. April 2010.

Womack, J. P., Jones, D. T., Roos, D. (1990): The machine that changed the World. Rawson Associates, New York

http://history.gmheritagecenter.com (Letöltés: 2017. március 1.)

https://www.audi.hu/hu/hirek/hirek/reszletek/514_audi_hungaria_stabil_eredmenyek_a_2016-os_ uzleti_evben/ (Letöltés: 2017. március 1.) 